\title{
Хірургічне лікування ускладненого аневризматичного субарахноїдального крововиливу
}

\author{
О. Ю. Полковніков
}

Запорізький державний медичний університет

\section{Surgical treatment of complicated aneurismal subarachnoidal hemorrhage}

\author{
O. Yu. Polkovnikov
}

Zaporizhzhya State Medical University

\section{Реферат}

Мета. Покращення результатів хірургічного лікування ускладненого аневризматичного внутрішньочерепного крововиливу.

Матеріали і методи. Із 213 хворих з субарахноїдальним крововиливом внаслідок розриву церебральних аневризм у 121 (56,8\%) хворого констатовано ускладнений перебіг. Усім цим хворим проведено хірургічне лікування, яке передбачало оклюзію аневризми.

Результати. У 68 (56\%) хворих застосовано мікрохірургічне кліпування, у 53 - ендоваскулярну емболізацію. Хірургічні втручання у 84,3\% хворих виконані протягом перших двох тижнів. У ряді спостережень застосовано комбіноване та багатоетапне хірургічне лікування. Позитивну динаміку отримано у 75 (61,9\%) хворих, у тому числі у 59 (48,8\%) хворих - хороший функціональний результат ( 1 - 2 ступінь інвалідизації за модифікованою шкалою Ренкіна). У 23 (19\%) хворих результат був несприятливий (4 - 5 ступінь інвалідизаціі). Померли 23 (19\%) пацієнти.

Висновки. Назріла потреба в нагальному напрацюванні уніфікованої класифікації ускладнень аневризматичного внутрішньочерепного крововиливу, вивченні ефективності різноманітних хірургічних методів лікування та визначенні критеріїв вибору методу та термінів виконання втручання у залежності від типу внутрішньочерепного крововиливу.

Ключові слова: церебральна аневризма; ускладнення; субарахноїдальний крововилив; хірургічне лікування.

Abstract

Objective. Improvement of the surgical treatment results of aneurisms, complicated by intracranial hemorrhage.

Materials and methods. Of 213 patients with subarachnoidal hemorrhage due to the cerebral aneurisms rupture in 121 (56.8\%) a complicated course was observed. In all the patients a surgical treatment was conducted, doing the aneurism occlusion. Results. In 68 (56\%) patients a microsurgical clipping, and in 53 - endovascular embolization was applied. Surgical interventions in $84.3 \%$ patients were performed during first two weeks. In some observations a combined and multi-staged surgical treatment was applied. Positive dynamics was obtained in 75 (61.9\%) patients, including 59 (48.8\%) patients with good functional result (degrees of disability $1-2$ in accordance to Renkin modified scale). In 23 (19\%) patients the result was unfavorable (degrees of disability 4-5), and 23 (19\%) patients died.

Conclusion. A timely necessity have evolved for elaboration of the unified classification of complications for complications of aneurysmal intracranial hemorrhage, as well as studying of efficacy of various surgical methods of treatment and determination of the method selection criteria and the terms of the intervention performance depending on the intracranial hemorrhage type present.

Keywords: cerebral aneurism; complications; subarachnoidal hemorrhage; surgical treatment.

Серцево-судинні захворювання є однією з найчастіших причин смертності та захворюваності населення в розвинених країнах світу. У США згідно зі статистикою 2014 р. у 795 тисяч людей інсульт діагностують щороку, із них у 610 тисяч - вперше [1]. Щорічно в Україні мозковий інсульт діагностують вперше у близько 100 тисяч людей, i третина цих хворих має працездатний вік.

Однією з найбільш агресивних форм інсульту є субарахноїдальний крововилив (САК) внаслідок розриву церебральної аневризми (ЦА). Типовий САК виявляють менш ніж у половини спостережень. У 13 - 40\% спостережень розрив ЦА супроводжується внутрішньошлуночковою геморагією, яка спричиняє грубу інвалідизацію та високу смертність - до 67 - 83\%. Формування внутрішньочерепних гематом, що ускладнюють перебіг аневризматичного САК, відбувається у 18 - 41\% пацієнтів. У середньому в 70\% спостережень під час ангіографічного обстеження виявляють ознаки ангіоспазму, який у 33,5\% спостережень призводить до погіршення стану аж до настання смерті [2].

Частота розвитку різновидів гідроцефалії на тлі аневризматичного внутрішньочерепного крововиливу становить від 6 до 67\% [3]. Існує взаємозв'язок між частотою розвитку ангіоспазму і гідроцефалії, що мають клінічні прояви [4].

31933 р., коли E. Bramwell запропонував градацію проявів ЦА на апоплектичні та паралітичні, було розроблено більш як 40 класифікацій щодо пацієнтів з ЦА [5]. Найчастіше для оцінки тяжкості САК використовують шкали Hunt-Hess та WFNS [6, 7]), а також шкали Fisher та Graeb, що спираються на критерії нейровізуалізації, зокрема, дані комп’ютерної томографії (КТ), проведеної під час госпіталізації пацієнта $[8,9]$. 
В останні роки проведені клінічні дослідження ISAT [10], BRAT [11], присвячені порівнянню ефективності мікрохірургічного та ендоваскулярного методів оклюзії ЦА. Водночас досліджень, метою яких є уніфікація лікування та профілактики ускладнень внутрішньочерепного крововиливу внаслідок розриву ЦА, вкрай бракує.

Мета дослідження: покращення результатів хірургічного лікування ускладненого аневризматичного внутрішньочерепного крововиливу.

\section{Матеріали і методи дослідження}

Проаналізовано результати хірургічного лікування пацієнтів з ускладненим аневризматичним внутрішньочерепним крововиливом з використанням мікрохірургічного та ендоваскулярного методів оклюзії розірваних ЦА у відділенні нейрохірургічної патології судин голови та шиї з рентгеноопераційною Інституту нейрохірургії імені А. П. Ромоданова НАМН України та відділенні нейрохірургії Запорізької обласної клінічної лікарні з 2014 по 2018 р. Із 213 пацієнтів із САК внаслідок розриву ЦА у 121 (56,8\%) спостерігали ускладнений перебіг.

Критеріями визначення ускладненого перебігу були: субарахноїдально-вентрикулярний, субарахноїдально-паренхіматозний або субарахноїдально-паренхіматозновентрикулярний крововилив, а також наявність ангіоспазму з клінічними проявами, відстрочена вторинна ішемія, візуалізована за допомогою КТ або магнітно- резонансної томографії (МРТ), порушення ліквородинаміки в різні строки впродовж геморагічного періоду. Ангіоспазм 3 клінічними проявами виявили у 58 (47,9\%) хворих, вторинну ішемію, підтверджену КТ або МРТ - у 38 (31,4\%), порушення ліквородинаміки в різні строки впродовж геморагічного періоду - у 27 (22,3\%), субарахноїдально-вентрикулярний крововилив - у 22 (18,1\%), субарахноїдально-паренхіматозний - у 35 (28,9\%), субарахноїдальнопаренхіматозно-вентрикулярний - у 31 (25,6\%) хворого.

У досліджуваній групі пацієнтів було 62 (51,2\%) жінки та 59 (48,8\%) чоловіків. Розподіл за віковими категоріями був таким: до 25 років - 4 (3,3\%) хворих, 25 - 45 років - 34 (28,1\%), 46 - 60 років - 63 (52,1\%), 61 - 75 років $-20(16,5 \%)$ хворих.

Оцінювали клінічний стан та неврологічний статус пацієнта на момент госпіталізації, під час та після лікування. Ступінь тяжкості САК визначали за допомогою шкали Hunt-Hess, ступінь інвалідизації на момент госпіталізації та під час виписки зі стаціонару - згідно з модифікованою шкалою Ренкіна (МШР). 3 метою визначення наявності та вираженості церебрального ангіоспазму виконували транскраніальну ультразвукову доплерографію судин головного мозку за допомогою ультразвукового діагностичного апарата LOGIQ P6 General Electric. Для нейровізуалізації типу крововиливу, характеру порушень ліквородинаміки, геморагічних та ішемічних ускладнень під час лікування, а також в окремих спостереженнях джерела крововиливу застосовували КТ головного мозку (комп'ютерний томограф Toshiba Asteion Super 4) та MPT (магнітнорезонансний томограф Hitachi Airis Mate 0,2 T та Hitachi Echelon 1,5 T). За даними церебральної ангіографії з використанням ангіографічних комплексів Siemens Axiom
Artis MP та Toshiba Infinix INFX 8000V VF-i/SP визначали локалізацію аневризми, особливості ії будови, ступінь вираженості ангіоспазму. Інвазивну церебральну ангіографію було проведено в 100\% спостережень. Усім хворим проведене хірургічне лікування, спрямоване на "вимкнення" аневризми з кровотоку.

\section{Результати}

Згідно зі шкалою Hunt-Hess тяжкість САК у 63 (52,1\%) хворих було оцінено як 1 - 2-й ступінь, у 33 (27,3\%) - як 3-й ступінь, у 20 (16,5\%) - як 4-й ступінь, у 5 (4,1\%) -як 5-й ступінь, тобто у 47,9\% хворих констатовано тяжкий або вкрай тяжкий крововилив.

На підставі комплексного аналізу клінічних проявів і даних нейровізуалізації була проаналізована залежність типу внутрішньочерепного крововиливу від локалізації ЦА (див. рисунок).

Звертає на себе увагу відсутність виражених порушень ліквородинаміки у разі розриву аневризм СМА, а також домінування аневризм комплексу ПМА-ПСА як джерела крововиливу з частим розвитком симптомного ангіоспазму, вторинної ішемії та гідроцефалії.

У 68 (56,1\%) хворих було застосовано мікрохірургічне кліпування розірваної ЦА, у 53 (43,8\%) - ендоваскулярну емболізацію відокремлюваними спіралями. Аналізуючи виконані хірургічні втручання, спрямовані на «вимкнення» ЦА з кровотоку, ми не уточнювали модифікацій і технічних особливостей ендоваскулярного та мікрохірургічного методів оклюзії аневризми.

Прооперовані протягом першого тижня 44 (36,4\%) пацієнти, протягом другого тижня - 58 (47,9\%), пізніше 15 діб - 19 (15,7\%), тобто хірургічні втручання у 84,3\% пацієнтів були виконані протягом перших двох тижнів.

У ряду пацієнтів з ускладненим внутрішньочерепним крововиливом було застосовано комбіноване та багатоетапне хірургічне лікування.

У 20 (29,4\%) із 68 хворих, яким застосували мікрохірургічне кліпування ЦА, одночасно видалили паренхіматозну гематому, у 30 (44,1\%) хворих виконали перфорацію термінальної платівки, у 8 (11,8\%) - вентрикулостомію.

У 3 (5,7\%) із 53 хворих, яким застосували ендоваскулярну оклюзію ЦА, одночасно виконали стентування ву-

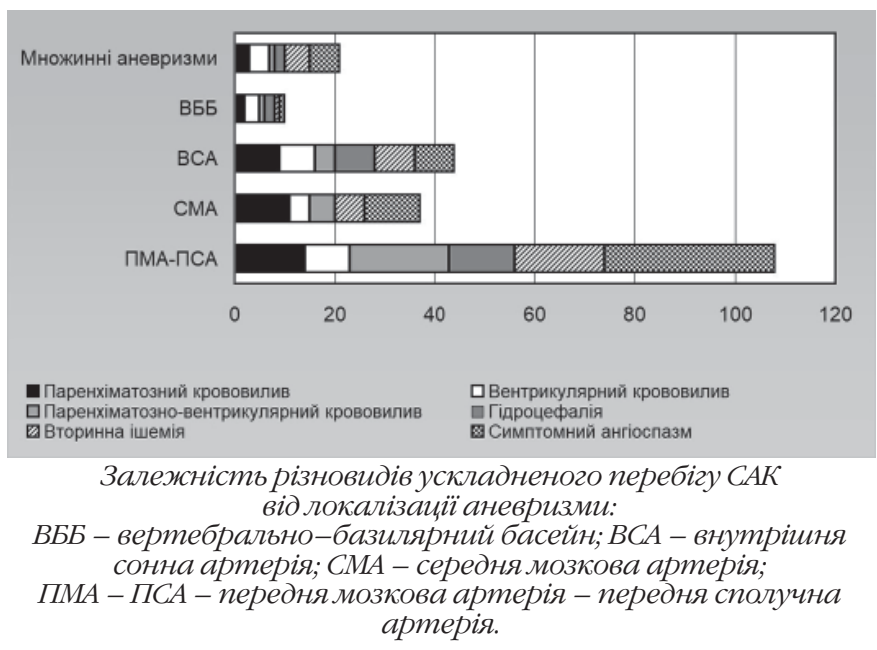


стя ВСА з приводу ії стенозу, у 2 (3,8\%) - балонну ангіопластику ангіоспазму, у 15 (28,3\%) - внутрішньоартеріальну фармакоангіопластику ангіоспазму німодипіном.

Після мікрохірургічної оклюзії ЦА декомпресивну краніектомію виконали 8 (11,8\%) пацієнтам, вентрикуло-перитонеальне шунтування - 5 (7,4\%).

Протягом 24 - 48 год після ендоваскулярної емболізації ЦА у 3 (5,7\%) хворих видалили паренхіматозну гематому, протягом 4 - 24 год виконали вентрикулостомію передніх рогів бічних шлуночків у 5 (9,4\%) хворих, у 4 (7,5\%) хворих застосували метод вентрикулярного фибрінолізу, у 3 (5,7\%) хворих виконали декомпресійну краніектомію.

Позитивну динаміку за даними оцінки функціонального статусу з використанням МШР спостерігали у 75 (61,9\%) хворих, у тому числі у 59 (48,8\%) хворих - хороший функціональний результат, що відповідав $1-2$ ступеню інвалідизації. У 23 (19\%) пацієнтів результат був несприятливий з грубою інвалідизацією (4 - 5 ступінь) на час виписки зі стаціонару. Померли 23 (19\%) пацієнти. Летальність прямо залежала від ступеня тяжкості САК за шкалою Hunt - Hess: 5 ступінь - 60\%, 4 ступінь - 35\%, 3 ступінь - 24,2\%, $1-2$ ступінь - 7,9\%.

Аналіз летальності в залежності від термінів виконання оперативного втручання виявив практично однакові показники після оклюзії ЦА протягом першого тижня $20,9 \%$ і протягом другого тижня - 21\%. Після виконання оклюзії ЦА пізніше 15 діб спостерігали зниження летальності до 10,5\%. Отримані результати відповідають даним, наведеним у літературі.

\section{Обговорення}

У більшості наукових робіт, присвячених проблемі аневризматичного внутрішньочерепного крововиливу, увагу приділено різним аспектам хірургічного лікування, спрямованого на оклюзію аневризми із застосуванням ендоваскулярного або мікрохірургічного методу. Однак результати лікування аневризматичних внутрішньочерепних крововиливів обумовлені не тільки особливостями хірургічної тактики, спрямованої на "вимкнення" аневризми 3 кровотоку, а й у великій мірі своєчасним усуненням дислокації мозку та порушень ліквородинаміки, а також профілактикою та комплексним лікуванням вторинних патологічних станів, що виникають впродовж геморагічного періоду.

Що стосується класифікацій, які використовують для градації тяжкості САК, то в більшості своїй вони базуються на оцінці рівня порушення свідомості, наявності або відсутності вогнищевої симптоматики або даних нейровізуалізації. Деякі з класифікацій об'єднують в собі як клінічні ознаки, так і дані нейровізуалізації (шкала С. J. Gerber i співавторів [12]). Останнім часом з'явилися класифікації для оцінки ймовірності розвитку вторинної ішемії, зокрема, VASOGRADE або шкала T. Inagava і співавторів $[13,14]$. Однак не існує шкал або градаційних систем, на підставі яких були б можливі прогнозування ймовірного сценарію перебігу захворювання та вибір оптимального методу хірургічного лікування.

У даний час нейрохірурги застосовують два ефективних методи оклюзіі ЦА - мікрохірургічне кліпування та ендоваскулярна емболізація, кожен з яких має свої переваги та недоліки. Однак немає чітких рекомендацій щодо вибору методу та термінів виконання втручання в залежності від типу крововиливу та його ускладнень.

\section{Висновки}

Для поліпшення результатів лікування такої тяжкої патології, як САК, яка призводить до високих показників інвалідизації та смертності, існує потреба в нагальному проведенні багатоцентрового клінічного дослідження, завданнями якого мають бути, по-перше, напрацювання уніфікованої класифікації ускладнень аневризматичного внутрішньочерепного крововиливу, по-друге, вивчення ефективності різноманітних хірургічних методів лікування ускладнених аневризматичних внутрішньочерепних крововиливів та профілактики порушень ліквородинаміки, по-третє, визначення критеріїв вибору методу та термінів проведення хірургічного лікування в залежності від типу внутрішньочерепного крововиливу.

\section{Підтвердження \\ Фінансування}

Ініціативно-пошукова робора. Фінансування публікації власним коштом.

\section{Конфлікт інтересів}

Автор декларує відсутність конфлікту інтересів щодо цього рукопису.

\section{References}

1. Go AS, Mozaffarian D, Roger VL, Benjamin EJ, Berry JD, Blaha MJ, et al. American Heart Association Statistics Committee and Stroke Statistics Subcommittee. Executive summary: heart disease and stroke statistics-2014 update: a report from the American Heart Association. Circulation. 2014 Jan 21;129(3):399-410. doi: 10.1161/01. cir.0000442015.53336.12.

2. Dorsch NW, King MT. A review of cerebral vasospasm in aneurysmal subarachnoid haemorrhage Part I: Incidence and effects. J Clin Neurosci. 1994 Jan;1(1):19-26. doi: 10.1016/0967-5868(94)90005-1.

3. Ohwaki K, Yano E, Nakagomi T, Tamura A. Relationship between shuntdependent after subarachnoid haemorrhage and duration of cerebrospinal fluid drainage. Br J Neurosurg. 2004 Apr;18(2):130-4. doi:10.108 $0 / 02688690410001680975$.

4. de Oliveira JG, Beck J, Setzer M, Gerlach R, Vatter H, Seifert V, et al Risk of shunt-dependent hydrocephalus after occlusion of ruptured intracranial aneurysms by surgical clipping or endovascular coiling: a singleinstitutio series and meta-analysis. Neurosurgery. 2007 Nov;61(5):924 33. doi: 10.1227/01.neu.0000303188.72425.24.

5. Rosen DS, Macdonald RL. Subarachnoid hemorrhage grading scales: a systematic review. Neurocrit Care. 2005; 2(2): 110-8. doi: 10.1385/ NCC:2:2:110

6. Hunt WE, Hess RM. Surgical risk as related to time of intervention in the repair of intracranial aneurysms. J Neurosurg. 1968 Jan; 28(1):14-20. doi: 10.3171/jns.1968.28.1.0014.

7. Teasdale GM, Drake CG, Hunt W, Kassell N, Sano K, Pertuiset B, et al. Report of World Federation of Neurological Surgeons Committee on a Universal Subarachnoid Hemorrhage Grading Scale. J Neurosurg. 1988 Jun; 68(6):985-6. PMID: 3236024.

8. Fisher CM, Kistler JP, Davis JM. Relation of cerebral vasospasm to subarachnoid hemorrhage visualized by computerized tomographic scanning. Neurosurgery. 1980 Jan;6(1):1-9. PMID: 7354892

9. Graeb DA, Robertson WD, Lapointe JS, Nugent RA, Harrison PB. Computed tomographic diagnosis of intraventricular hemorrhage. Etiology and prognosis. Radiology. 1982 Apr; 143(1):91-6. doi:10.1148/radiology.143.1.6977795. 
10. Darsaut TE, Jack AS, Kerr RS, Raymond J. International Subarachnoid Aneurysm Trial - ISAT part II: study protocol for a randomized controlled trial. Trials. 2013 May 29;14:156. doi: 10.1186/1745-621514-156.

11. Spetzler RF, McDougall CG, Zabramski JM, Albuquerque FC, Hills NK, Russin JJ, et al. The Barrow Ruptured Aneurysm Trial: 6-year results. J Neurosurg. 2015 Sep;123(3):609-17. doi: 10.3171/2014.9.JNS141749.

12. Gerber CJ, Lang DA, Neil-Dwyer G, Smith PW. A simple scoring system for accurate prediction of outcome within four days of a subarachnoid haemorrhage. Acta Neurochir (Wien). 1993;122(1-2):1122. PMID: 8333301
13. de Oliveira Manoel AL, Jaja BN, Germans MR, Yan H, Qian W, Kouzmina E, Marotta TR, Turkel-Parrella D, Schweizer TA, Macdonald RL. The VASOGRADE: A Simple Grading Scale for Prediction of Delayed Cerebral Ischemia After Subarachnoid Hemorrhage. Stroke. 2015 Jul;46(7):1826-31. doi: 10.1161/STROKEAHA.115.008728.

14. Inagawa T, Yahara K, Ohbayashi N. Risk factors associated with cerebral vasospasm following aneurysmal subarachnoid hemorrhage. Neurol Med Chir (Tokyo). 2014 Jun 17;54(6):465-73. doi: 10.2176/nmc. oa.2013-0169.

Отримана 02.10.2018 